\title{
PENINGKATAN KINERJA PADA PROSES PRODUKSI OLAHAN BERBASIS APEL DI UKM TM MANDIRI DAN MULYO AGRO MANDIRI, KOTA BATU
}

\author{
Increasing Performance in Apple Based Products Production \\ at SMEs TM Mandiri and Mulyo Agro Mandiri, Batu City
}

Teti Estiasih dan Ella Saparianti

PS Ilmu dan Teknologi Pangan, Jurusan Teknologi Hasil Pertanian, Fakultas Teknologi Pertanian, Universitas Brawijaya, Jl. Veteran, Malang

\begin{abstract}
Two small and medium enterprises (SMEs) in Kota Batu, SME Mulyo Agro Mandiri and TM Mandiri, have contributed to the production of unique apple-based food products that produce semprit apel and lilit apel. SME Mulyo Agro Mandiri has also pioneered the production of sambel apel and SME TM Mandiri began to develop the production of apple pie. IbM program that has been implemented is to increase capacity and efficiency of apple based product production, standard operating procedure (SOP), and improvement of semprit apel packaging and diversification of apple pie product. Facilitation equipment for increasing efficiency and production capacity in SMEs Mulyo Agro Mandiri in the form of planetary mixer, sambel aple grinder, and pedal sealer. Facilitation in SME TM Mandiri in the form of grater, oven, stainless steel working table, and sheeter. SME Mulyo Agro Mandiri has developed its product in the form of an sambel apel that requires sambel grinder. Product development in SME TM Mandiri is apple pie that needs oven for baking. This facilitation has improved the efficiency of the production process. Efficiency of semprit apel dough in SME Mulyo Agro Mandiri increased from $5 \mathrm{~kg} / 0.5 \mathrm{~h}$ to $12.5 \mathrm{~kg} / 0.5 \mathrm{~h}$. A $100 \%$ reduction in damage packaging is due to facilitation of pedal sealer that replaced hand sealer. Sambel apel grinding is improved from manual to continuous mechanical grinding. In SME TM Mandiri, the baking capacity of apple pie increased from 1 dough / batch to 3 dough / batch. Dough sheeting for kue lilit apel becomes faster by using a sheeter machine, as well as apple grater. The presence of a stainlesssteel working table improves their higienity. SOPs have been accomplished and implemented.
\end{abstract}

Keywords: product diversification, effciency, production capacity, SOP

\begin{abstract}
ABSTRAK
Dua usaha kecil menengah (UKM) di Kota Batu yaitu UKM Mulyo Agro Mandiri dan TM Mandiri telah berkontribusi dalam memproduksi olahan pangan berbasis apel yang unik yang memproduksi kue semprit apel dan kue lilit apel. UKM Mulyo Agro Mandiri juga sudah merintis produksi sambel apel dan UKM TM Mandiri mulai mengembangkan produksi pie apel. Program IbM yang telah dilaksanakan berupa peningkatan kapasitas dan efisiensi produksi olahan apel, pembuatan standard operating procedure (SOP) produksi kue semprit apel dan kue lilit apel, serta perbaikan kemasan kue semprit apel dan diversifikasi produk kue lilit apel. Fasilitasi peralatan untuk peningkatan efisiensi dan kapasitas produksi di UKM Mulyo Agro Mandiri berupa planetary mixer, penghalus sambel apel, dan pedal sealer. Fasilitasi di UKM TM Mandiri berupa mesin pemarut, oven, meja kerja stainless steel, dan sheeter. UKM Mulyo Agro Mandiri telah mengembangkan produknya berupa sambel apel yang memerlukan alat penghalus sambel. Pengembangan produk di UKM TM Mandiri berupa pie apel yang membutuhkan oven untuk pemanggangan. Adanya fasilitasi ini telah meningkatkan efisiensi proses produksi. Efisiensi pengadonan adonan kue semprit apel di UKM Mulyo Agro Mandiri dari $5 \mathrm{~kg} / 0,5$ jam menjadi $12,5 \mathrm{~kg} / 0,5$ jam. Terjadi penurunan kemasan yang rusak sebesar $100 \%$ akibat pengemasan yang tidak tepat menggunakan hand
\end{abstract}


sealer setelah introduksi alat pedal sealer. Penghalusan sambel apel yang asalnya manual menjadi mekanis dan kontinyu. Di UKM TM Mandiri, kapasitas pemanggangan pie apel meningkat dari 1 adonan/batch menjadi 3 adonan/batch. Pencetakan adonan menjadi lebih cepat dengan menggunakan mesin sheeter, demikian pula dengan pemarutan apel. Adanya meja kerja stainless steel telah membantu mitra untuk meningkatkan sanitasinya. SOP telah disusun dan diimplementasikan.

Kata kunci: diversifikasi produsk, efisiensi, kapasitas produksi, SOP

\section{PENDAHULUAN}

Kota Batu saat ini telah menjadi destinasi wisata terkenal di Indonesia (Wikipedia, 2016). Berbagai obyek wisata yang ada di Kota Batu telah menarik wisatawan terutama domestik untuk datang ke Kota Batu, sehingga Kota Batu merupakan kota agrowisata yaitu kota wisata berbasis pertanian. Efek berganda (multiplier effects) dari berkembangnya pusat-pusat wisata di Kota Batu adalah maraknya usaha kecil, mikro, dan menengah (UMKM) yang memproduksi makanan oleh-oleh khas Kota Batu. Kota Batu terkenal dengan produksi apelnya yang pada tahun 2013 berjumlah 5,1 ton (BPS Kota Batu, 2015). Kelimpahan apel di Kota Batu dan sekitarnya telah mendorong banyak UMKM dan industri rumah tangga untuk memproduksi berbagai pangan olahan berbasis apel.

Menurut Boyer (2004), keunggulan apel adalah banyak mengandung senyawa fenolik yang berperan sebagai antioksidan. Penelitian epidemiologis menunjukkan bahwa apel bersifat mencegah penyakit kanker, kardiovaskular, asma dan penyakit paru, serta diabetes. Menurut Hyson (2011), jenis fenol yang ada pada apel adalah flavonoid $(60 \%)$ dan asam fenolat $(30 \%)$. Adanya senyawa fitokimia dalam apel menyebabkan apel mempunyai peran mencegah berbagai jenis kanker seperti kanker kolon, payudara, menjaga kesehatan tulang, dan mencegah pencernaan dari perlukaan akibat obat-obatan. Apel juga mengandung senyawa fenolik yang berperan menghambat enzim $\alpha$ glukosidase sehingga menurunkan indeks glikemik (Adyanthaya et al., 2009).

Untuk berkembang dan meraih pangsa pasar, UMKM harus selalu berinovasi dalam pengembangan produk dengan membidik produk yang belum ada di pasaran. Dua usaha kecil menengah (UKM) di Kota Batu yaitu UKM Mulyo Agro Mandiri dan TM Mandiri telah berkontribusi dalam memproduksi olahan pangan berbasis apel yang unik yang memproduksi kue semprit apel dan kue lilit apel. Kue semprit apel merupakan kue semprit berbahan baku tapioka dengan campuran buah apel. Kue lilit apel merupakan kue dengan isian apel yang dililit oleh adonan tepung dan digoreng. Kue lilit apel ini terinspirasi oleh kue lilit sale atau pisang yang telah ada di pasaran. Hanya saja, karena berbahan apel, maka proses pengolahannya mengalami modi-fikasi. Kedua UKM mempunyai peluang untuk berkembang dengan pasar potensial untuk diperluas. Tidak adanya pesaing, rasa yang enak, dan produk yang unik menjadikan kedua produk ini akan mudah untuk mendapatkan market gain. Didukung Kota Batu sebagai kota agrowisata dengan sebagian besar oleh-oleh berbasis hortikultura terutama apel, menyebabkan perluasan pasar kedua produk ini akan mudah dilakukan.

Akan tetapi kedua mitra mempunyai permasalahan yaitu kapasitas produksi dan efisiensi produksi yang rendah. Permasalahan pada UKM Mulyo Agro Mandiri adalahproses produksi yang tidak efisien dengan titik kritis lambatnya proses produksi adalah pada proses pengadonan/mixing. Masalah lain adalah proses pengemasan yang menggunakan manual hand sealer yang seringkali rusak. 
Selain itu proses produksi yang belum terstandar dan terdokumentasi.

Permasalahan yang dihadapi UKM TM Mandiri pada proses produksi kue lilit apel adalah kapasitas produksi yang kecil. Titik kritis utama adalah pada proses pembuatan lembaran adonan (sheeting) menggunakan pencetak mie skala rumah tangga. Pemarutan manual memakan waktu lama sedangkan pemarutan ke pasar menyebabkan warna apel parut menjadi cokelat tua yang tidak menarik. Perubahan warna tersebut disebabkan oleh reaksi pencokelatan enzimatis akibat reaksi oksidasi senyawa fenol oleh enzim polifenol oksidase dengan adanya oksigen (Lu et al., 2007). Selain itu, untuk me-ningkatkan higienisitas selama pencetakan dan pelilitan, diperlukan working table yang mudah dibersihkan dan proses peletakkan lembaran adonan yang sudah dicetak bisa diletakkan di atas meja. Proses produksi yang belum terstandar dan terdokumentasi juga merupakan permasalahan UKM TM Mandiri.

\section{METODE PELAKSANAAN}

\section{Peningkatan Kinerja pada Produksi Kue Semprit Apel}

Peningkatan kinerja proses produksi kue semprit apel dilakukan dengan cara meningkatkan efisien pengadukan adonan untuk kue semprit apel, dan penghalusan adonan, pengemasan. Peningkatan efisiensi pengadukan dilakukan dengan meningkatkan kapasitas pengadonan menggunakan planetary mixer yang dilengkapi dengan tiga jenis blade sesuai kebutuhan. Selama ini mitra menggunakan mixer rakitan sendiri yang sebenarnya sesuai untuk adonan cair (batter). Planetary mixer yang difasilitasikan kepada mitra mempunyai blade yang sesuai untuk adonan kental atau padat (dough) sehingga akan meningkatkan efisieni pengadukan.

Mitra juga memproduksi sambel apel. Proses penggilingan sampbel dilakukan dnegan menggunakan mesin penggiling manual sehingga mempunyai keterbatasan daya. Peningkatanefisiensi penghalusan sambel apel dilakukan dengan fasilitasi penghalus bumbu basah sistem kontinyu.

Permasalahan lain yang dihadapi mitra dalam pengemasan kue semprit apel adalah kualitas pengemasan yang kurang baik akibat penggunakan hand sealer dengan daya rekat yang kurang. Akibatnya pengemasan tidak sempurna dan menyebabkan produk kue semprit mitra mudah melempem. Fasilitasi pengemas pedal sealer diharapkan dapat meningkatkan kualitas pengemasan produk UKM TM Mandiri.

\section{Peningkatan Kinerja pada Produksi Kue Lilit Apel}

Peningkatan kinerja pada proses produksi kue lilit apel dilakukan dengan meningkatkan efisiensi pemarutan melalui fasilitasi alat pemarut untuk apel. Mitra juga melakukan diversifikasi produk olahan apel berup pie apel. Selama ini proses pemanggangan pie apel menggunakan oven kecil skala rumah tangga. Peningkatan kapaitas pemanggangan dilakukan pada Program IbM ini dengan fasilitasi oven pemanggang dua tingkat dengan api bawah dan api atas. Selama ini proses pencetakan kuliat kue apel lilit dilakukan menggunakan pencetak mie manual. Proses sheeting ditingkatkan efisiensinya dengan fasilitasi mesin sheeter. Peningkatan higienisitas pada proses pencetakan kulit kue apel lilit dilakukan dengan fasilitasi meja kerja yang terbuat dari stainless steel sehingga mudah dibersihkan.

\section{Standarisasi Proses}

Standarisasi proses dilakukan dengan pada tahapan kritis dalam pengolahan kue semprit dan kue lilit apel. Standarisasi proses dilakukan dengan menyusun Standard Operating Procedure (SOP) dengan didiskusikan Bersama mitra. SOP tersebut kemudian diverifikasi dalam proses pengolahan sebelum divalidasi dan dijadikan standar dalam proses produksi. 
Penjaminan mutu produk untuk mendapatkan kualitas kue semprit apel dan kue lilit apel yang konsisten perlu dilakukan dengan menerapkan SOP yang telah disusun.

\section{HASIL DAN PEMBAHASAN}

\section{Peningkatan Kinerja Produksi Kue Semprit Apel}

Untuk meningkatkan efisiensi produksi kue semprit apel dan sambel apel, UKM Mulyo Agro Mandiri telah difasilitasi alat planetary mixer, penghalus sambel apel, dan pedal sealer. Peningkatan efisiensi produksi kue semprit apel yang dibutuhkan mitra adalah peningkatan efisiensi pengadukan/mixing adonan dan pencetakan. Mitra selama ini mempunyai mixer yang dirakit sendiri. Mixer tersebut mempunyai performansi yang kurang bagus karena rakitan sendiri. Mixer yang dipilih adalah mixer tipe planetary multifungsi yang untuk adonan cair (batter), adonan kalis (dough), dan pencampur (mixing). Planetary mixer (Gambar 1) dengan kapasitas 20 L. Adanya alat ini telah membantu mitra mengefisienkan proses pengadukan adonan.

Selama ini proses pengadonan 1 batch memerlukan waktu 0,5 jam. Dengan adanya alat ini, proses pengadonan bisa meningkat menjadi $12,5 \mathrm{~kg}$ untuk 0,5 jam. Artinya terjadi peningkatan efisiensi waktu sebesar $250 \%$ atau kapasitas pengadonan meningkat 2,5 kali lipat. Alat ini juga dilengkapi oleh tiga jenis pengaduk sesuai dengan kebutuhannya. Pengaduk yang pertama adalah untuk adonan cair (batter), pengaduk yang kedua adalah untuk adonan krim, dan pengaduk ketiga untuk adonan yang bersifat kalis seperti mie dan roti. Dengan fasilitasi alat ini, UKM Mulyo Agro Mandiri mempunyai alat untuk pengembangan produknya karena alat ini memungkinkan digunakan untuk berbagai proses pengadonan.

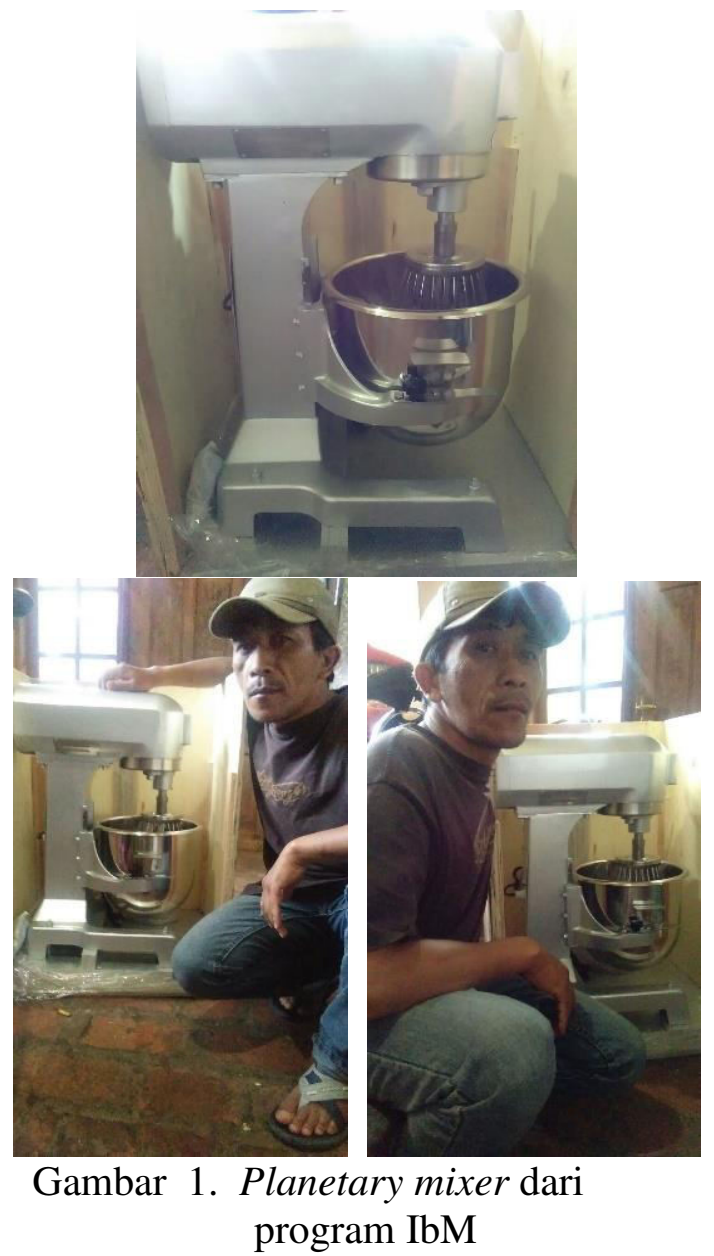

Fasilitasi penghalus sambel apel yang merupakan salah satu cara untuk meningkatkan efisieni proses pengolahan sambel apel. Alat tersebut dapat dilihat pada Gambar 2. Penghalusan sambel apel bersifat kontinyu. Sebelum penghalusan, bahan-bahan dikukus terlebih dahulu meliputi cabe merah, cabe rawit, bawang merah, bawang putih, dan irisan apel. Tujuannya adalah proses blansing untuk melunakkan tekstur dan menginaktivasi enzim-enzim fenolase yang menyebabkan warna menjadi cokelat atau gelap. Menurut AKtas et al. (2007), blansing bertujuan menginaktivasi enzim-enzim yang menyebabkan kerusakan sayuran segar seperti peroksidase dan polifenol oksidase. 


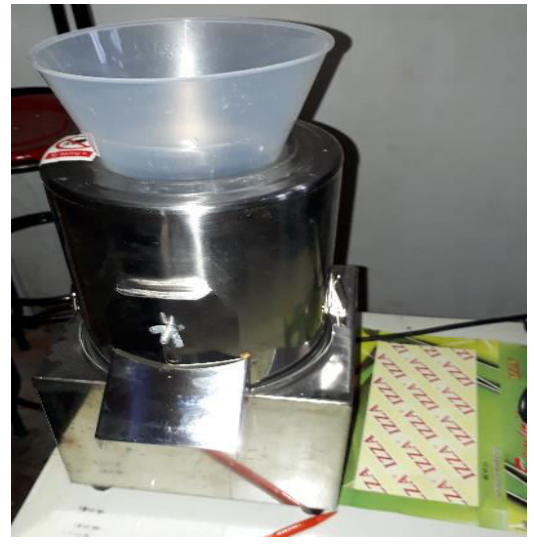

Gambar 2. Penghalus sambel apel

Sebelum pelaksanaan program, mitra sering gagal dalam proses pengemasan yang menyebabkan kemasan bocor sehingga produk mudah melempem. Selama ini mitra menggunakan pengemas manual (hand sealer) yang sering kurang panas sehingga proses penyegelan (sealing) menjadi tidak sempurna. Ketidak-sempurnaan penyegelan kemasan me-nyebabkan produk mudah rusak. Kue semprit apel akan mudah melempen jika kemasan bocor akibat produk menyerap uap air dari udara yang masuk ke dalam kemasan. Akibatnya produk menjadi tidak renyah. Menurut Antonova et al. (2003), kerenyahan merupakan penentu tekstur utama untuk produk-produk yang kering. Perbaikan proses pengemasan dapat diatasi dengan menggunakan mesin pengemas yang lebih canggih yaitu pedal sealer. Dengan menggunakan alat ini, tingkat kerusakan kemasan akibat pengemasan yang tidak sempurna dapat diminimumkan.

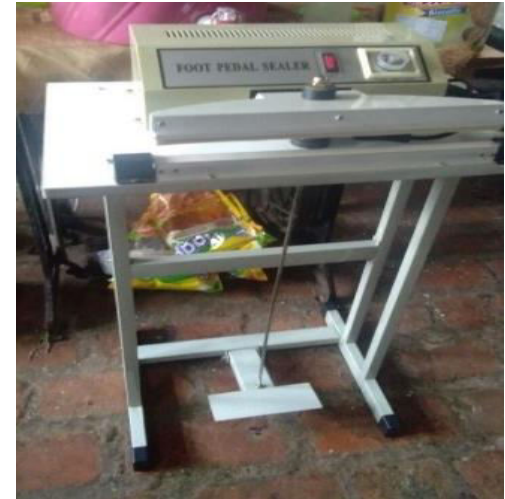

Gambar 3 Pedal sealer dan spesifikasinya

Fasilitasi peralatan yang dibutuhkan oleh UKM Mulyo Agro Mandiri telah mampu mengefisienkan proses produksi di mitra. Efisiensi proses dan peningkatan kapasitas produksi tersebut dapat dilihat pada Tabel 1.

\section{Peningkatan Efisiensi Produksi Kue Lilit Apel}

Peningkatan kapasitas pemarutan merupakan titik kritis karena UKM TM Mandiri tidak mempunyai mesin pemarut sehingga pemarutan dilakukan secara manual. Pemarutan manual memerlukan waktu lama. Alternatif lain yang sering dilakukan mitra adalah pemarutan di pasar tetapi seringkali memerlukan waktu lama karena jarak tempuh dan antri alat. Alat pemarut diberikan kepada mitra dapat dilihat pada Gambar 4. Alat tersebut mempunyai kapasitas $50 \mathrm{~kg} / \mathrm{jam}$ sehingga proses pemarutan mitra berjalan sangat cepat. Pemarutan ini diperlukan untuk pemarutan apel pada proses pembuatan selai apel. Selai apel ini yang digunakan sebagai bahan isian kue lilit apel.

Tabel 1. Peningkatan efisiensi produksi kue semprit apel dan sambel apel di UKM Mulyo Agro Mandiri

\begin{tabular}{lll}
\hline \multicolumn{1}{c}{ Fasilitasi } & \multicolumn{1}{c}{ Luaran } & \multicolumn{1}{c}{ Capaian Indikator } \\
\hline Planetary mixer & Peningkatan efisiensi & Efisiensi mixing meningkat $5 \mathrm{~kg} / 0,5$ \\
& pengadukan/mixing adonan & jam menjadi $12,5 \mathrm{~kg} / 0,5 \mathrm{jam}$ \\
Penghalus sambel & Peningkatan efisiensi & Penghalusan manual menjadi \\
apel & penghalusan sambel pecel & penghalusan mekanis \\
Pedal sealer & Peningkatan kualiats & Tidak ada kemasan yang rusak \\
& pengemasan & \\
\hline
\end{tabular}




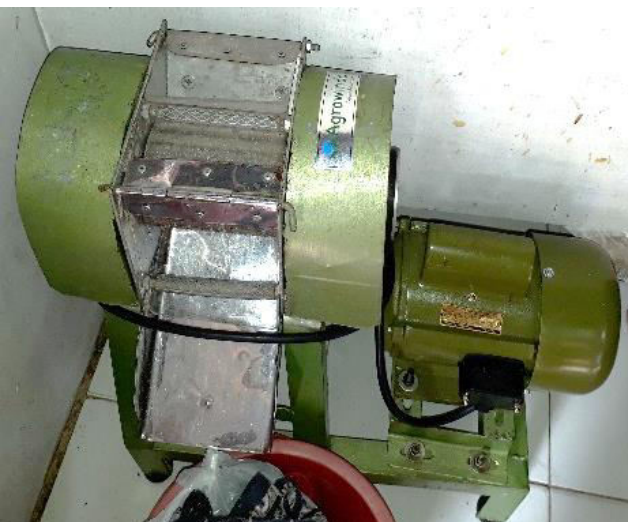

Gambar 4. Mesin pemarut

Selanjutnya pada proses pengolahan kue apel lilit, selai apel yang sudah dibentuk memanjang tersebut dililit dengan adonan. Adonan tersebut terlebih dahulu dipipihkan menggunakan alat sheeter seperti ditunjukkan Gambar 5. Selama ini UKM TM Manditi menggunakan sheeter dengan alat pembuat mie manual. Peningkatan efisiensi pencetakan dapat meningkatkan kapasitas sheeting yang selama ini menggunakna mesin pencetak mie skala rumah tangga. Proses pencetakan ini dilakukan secara manual dengan menggunakan putaran tangan. Pencetakan lembaran (sheeting) dilanjutkan dengan pemotongan (cutting) dapat dilakukan secara simultan menggunakan mesin otomatis sehingga proses berjalan lebih cepat.
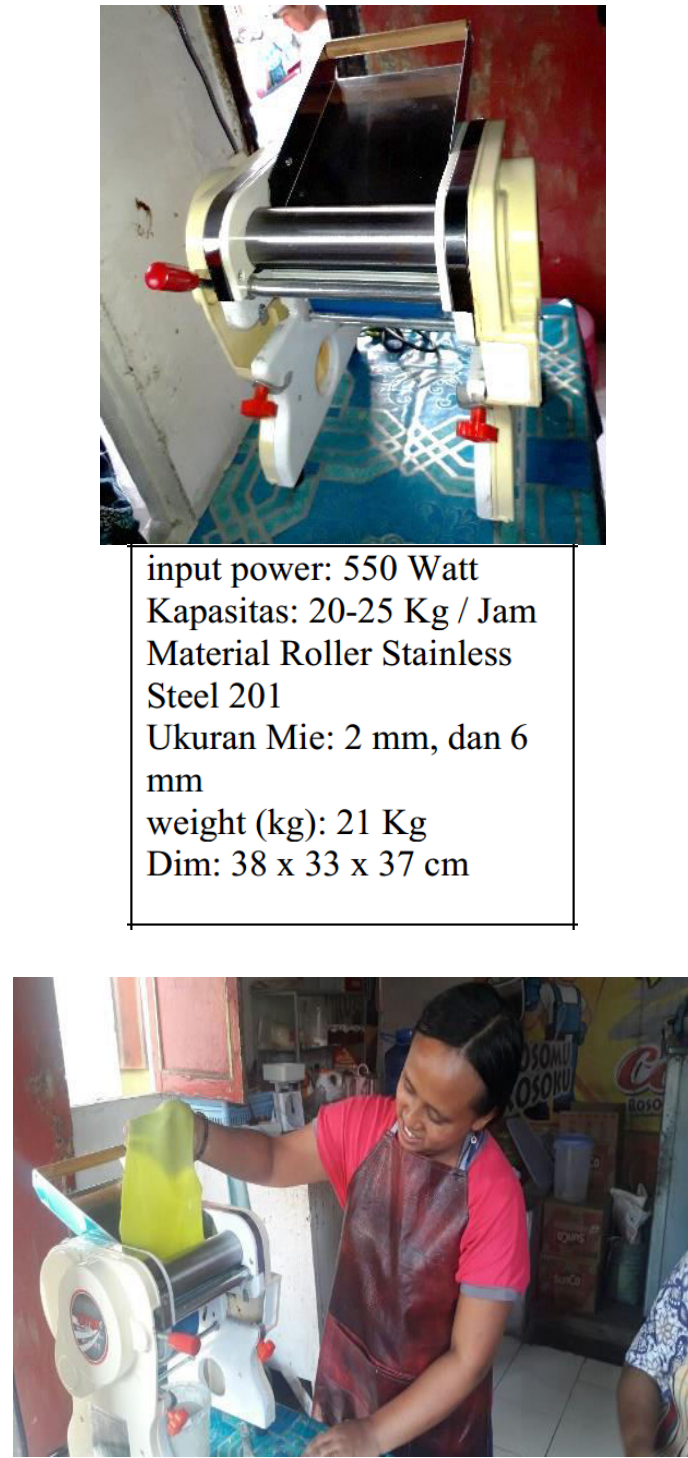

Gambar 5. Mesin sheeter dan spesifikasinya

Tabel 2. Peningkatan efisiensi dan kapasitas produksi kue lilit dan pie apel

\begin{tabular}{|c|c|c|}
\hline Fasilitasi & Luaran & Capaian Indikator \\
\hline Mesin pemarut & $\begin{array}{l}\text { Peningkatan efisiensi } \\
\text { pemarutan apel }\end{array}$ & $\begin{array}{l}\text { Peningkatan efisiensi pemarutan dari } 20 \mathrm{~kg} / 2 \mathrm{jam} \\
\text { menjadi } 20 \mathrm{~kg} / 30 \text { menit } \\
\text { Warna produk cokelat menjadi tidak cokelat }\end{array}$ \\
\hline Sheeter & $\begin{array}{l}\text { Peningkatan efisiensi } \\
\text { pencetakan }\end{array}$ & $\begin{array}{l}\text { Lama pencetakan } 4 \text { jam menjadi } 1 \text { jam untuk } \\
\text { setiap } 20 \mathrm{~kg} \text { adonan }\end{array}$ \\
\hline Oven & $\begin{array}{l}\text { Peningkatan efisiensi } \\
\text { pemanggangan pie apel }\end{array}$ & $\begin{array}{l}\text { Peningkatan kapasitas pemanggangan dari } 1 \\
\text { adonan per batch menajdi } 3 \text { adonan per batch }\end{array}$ \\
\hline Working table & Peningkatan higienisitas & $\begin{array}{l}\text { Bahan menjadi tidak lengket di meja } \\
\text { Lebih mudah dibersihkan } \\
\text { Lebih higienis }\end{array}$ \\
\hline
\end{tabular}


UKM TM Mandiri juga sudah mulai merintis pengembangan produk pie apel selain produk lilit apel yang juga tetap diproduksi. Untuk produksi pie apel tersebut, mitra memerlukan fasilitasi oven pemanggang. Dengan oven ini, produksi pie apel dapat meningkatkan 4 kali lipat kapasitas produksi sebelum program. Melalui fasilitasi alat ini, UKM TM Mandiri dapat mengembangan produksi produk pangan multi varian sehingga tidak hanya bertumpu pada satau jenis produk saja.

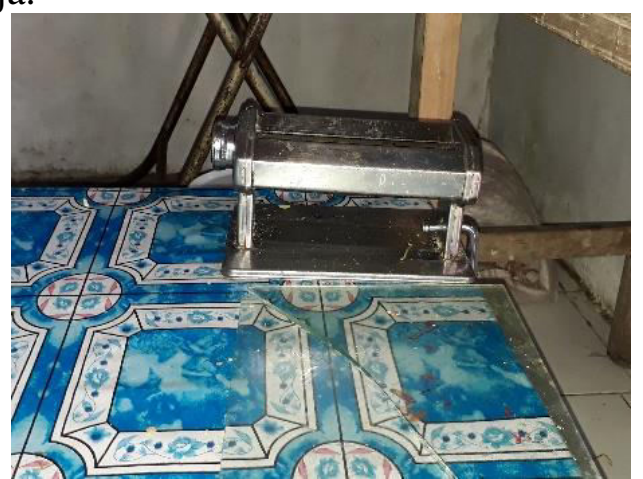

(a)

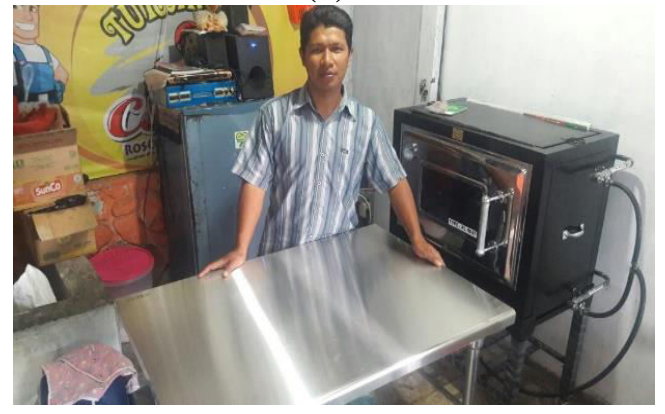

(b)

Gambar 6. Meja yang digunakan sebelum program (a) dan meja stainless steel (b)

Fasilitasi peralatan produksi kue lilit apel dan pie apel telah berhasil meningkatkan kapasitas dan efisiensi produksi kedua jenis produk tersebut. Peningkatan efisiensi dan kapasitas produksi tersebut dapat dilihat pada Tabel 2.

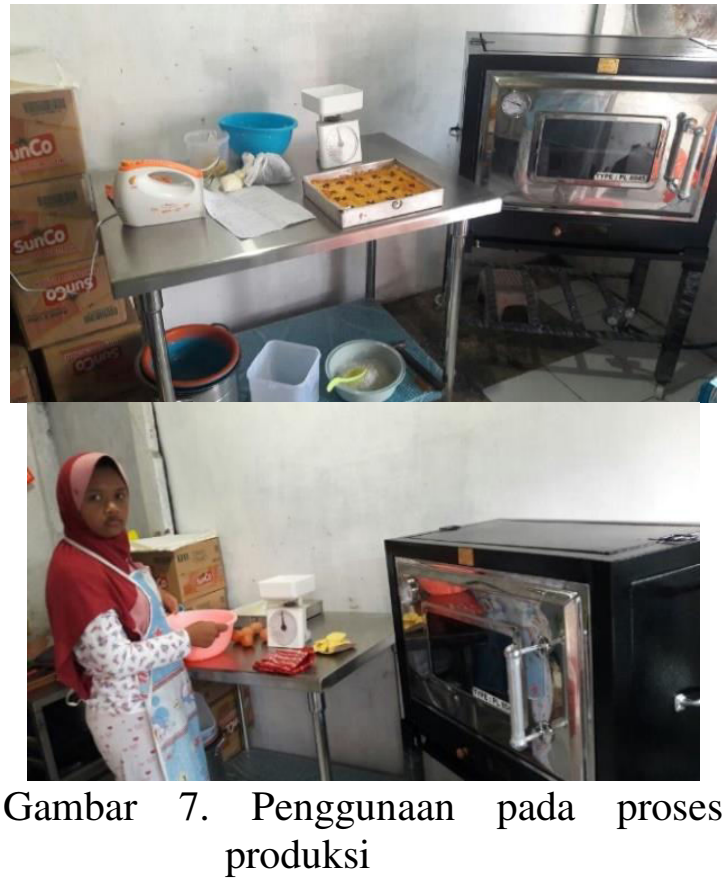

\section{Standarisasi Proses Produksi Kue Semprit Apel dan Kue Lilit Apel}

Pembuatan Standard Operating Procedure (SOP) dilakukan setelah semua fasilitasi peralatan untuk kedua mitra telah diterima dan digunakan. SOP proses sangat erat kaitannya dengan spesifikasi dan performansi peralatan. Tahapan proses produksi yang memerlukan SOP adalah tahapan proses produksi yang merupakan titik kritis terhadap mutu dan keamanan pangan. Tahapan proses produksi produk kue semprit apel dan lilit apel berbeda sehingga SOP untuk keduanya juga berbeda.

SOP yang dibutuhkan olehUKM Mulyo Agro Mandiri pada proses produksi kue semprit apel meliputi SOP pemilihan bahan baku, SOP pengadukan/mixing, SOP pencetakan. Proses pengolahan kue semprit apel di UKM Mulyo Agro Mandiri telah memenuhi sanitasi pekerja yaitu mitra menggunakan sarung tangan, penutup kepala, celemek, dan masker ketika produksi. Akan tetapi sanitasi ruangan dan peralatan mitra masih harus ditingkatkan. Ruang produksi mitra sebenarnya belum memnuhi syarat sanitasi ruang yang baik karena lantainya tidak diberi lapisan yang mudah dibersihkan. Ruang produksi saat ini adalah rumah 
kontrakan dan mitra sedang membangun sendiri ruang produksinya sehingga diharapkan ke depan kondisi sanitasi ruangan produksi lebih baik.

SOP yang dibutuhkan oleh UKM TM Mandiri UKM TM Mandiri pada proses produksi kue lilit apel meliputi SOP pemilihan bahan baku, SOP pemarutan, SOP pemasakan, SOP pencetakan, dan SOP penggorengan. Seperti halnya UKM Mulyo Agro Mandiri, kondisi sanitasi ruangan di UKM TM Mandiri juga belum sepenuhnya memenuhi syarat sanitasi. Upaya perbaikan sanitasi ruangan terus diupayakan mitra karena mitra sudah mengajukan No. P-IRT tetapi gagalakibat sanitasi yang belum terpenuhi. Hal ini juga menjadi perhatian dari Dinas Kesehatan (Dinkes) Kota Batu sebagai badan yang mengeluarkan No. P-IRT. Untuk itu mitra telah melakukan upayaupaya perbaikan sesuai saran Dinkes dan Tim IbM seperti penggunaan kasa kawat untuk ventilasi dan penataan peralatan serta menjaga kebersihannya.

\section{KESIMPULAN}

Peningkatan kinerja pada proses produksi kue semprit apel dan lilit apel dilakukan dengan meningkatkan kapasitas pengadukan dan efisiensi pengemasa pada produksi kue semprot apel Peningkatan kinerja produksi kue lilit apel dilakukan dengan meningkatkan efisiensi dan kapasitas pencetakan adonan, peningkatan kapasitas dan efisiensi pemarutan apel, serta peningkatan higienisitas proses produksi. Penerapan SOP dilakukan untuk menghasilkan produk kue semprit apel dan lilit apel yang terstandar.

\section{DAFTAR PUSTAKA}

Adyanthaya, I, Y.I. Kwon, E. Apostolidis, K. Shett. 2009. Health benefits of apple phenolics from postharvest stages for potential type 2 diabetes management using in vitro models. Journal of Food Biochemistry 34(1): 31-49.

Aktas, T., S. Fujii, Y. Kawano, S. Yamamoto. 2007. Effects of pretreatments of sliced vegetables with trehalose on drying characteristics and quality of dried products. Food and Bioproducts 85(3): 178-183.

Antonova, I., P. Mallikarjunan, S.E. Dun. 2003. Correlating objective measurements of crispness in breaded fried chicken nuggets with sensory crispness. Journal of Food Science 68(4): 1308-1315.

Biro Pusat Statistik [BPS]. 2015. Kota Batu dalam Angka. BPS Kota Batu.

Boyer, J. dan R.H. Liu. 2004. Apple phytochemicals and their health benefits. Nutrition Journal 3:5.

Hyson, D.A. 2011. A comprehensive review of apples and apple components and their relationship to human health. Adv. Nutr. 2: 408420. DOI:10.3945/an.111.000513

Lu, S., Y. Luo, E. Turner, H/ Feng. 2007. Efficacy of sodium chlorite as an inhibitor of enzymatic browning in apple slices. Food Chemistry 104: 824-829

Wikipedia, 2016. Kota Batu. https://id.wikipedia.org/wiki/Kota_B atu. Tanggal akses 3 Mei 2016, pukul 02.26. 